INTERMEZZO 



\section{Karl Heinzen}

\section{Mord og frihed - et bidrag til Geneves 'fredsliga' (1853)}

Der findes en række tekniske betegnelser for den vigtige handling, hvormed et menneske ødelægger en andens liv. De er: dræbe, myrde, skyde, slå ned, forgifte, bringe ud af verden, deportere til Cayenne, få af vejen, halshugge, strangulere, garrottere, hugge ned, ramme med sværdet, skyde ned, indespærre for livet, henrette etc. Måderne, påskuddene og årsagerne er forskellige, men målet er altid det samme, nemlig udryddelsen af et fjendtligt eller besværligt menneskeliv. Set ud fra retfærdighedens og humanitetens synsvinkel da er ødelæggelsen af en andens liv altid uretfærdigt og barbarisk, hvad end det sker på skafottet eller slagmarken, i morderens hule eller duelpladsen, i fængslet eller på gaden. Humanitetens sprogbrug har derfor ingen tålmodighed med de spidsfindige forskelle, med hvilke det dominerende barbari på den ene side påstår et retmæssigt drab, mens et andet fordømmes som et strafbart drab. Humaniteten må absolut fordømme al drab, da hun henviser alle fjendtlige konflikter mellem mennesker til fornuftens og ikke til styrkens tribunal. Hun er derfor kun konsistent, når hun bestemmer al frivillig udryddelse af et andet menneskes liv med det fordømmende udtryk mord. Hendes eneste beskæftigelse kan kun være at afskaffe mord. Men så længe som mord er den eneste måde at opnå dette på, da er humaniteten også pånødet at drage sværdet og blive mordere af morderne. Hvis det tillades én at myrde, da må det være tilladt alle, og særligt de, der myrder for at udrydde dem, som er mordere af profession eller af 'guds nåde'.

Kun stupid svaghed ville med sentimental jammer undvige betydningen af det vældige faktum, at mord i dets mest kolossale dimensioner har været og er det primære middel til historisk udvikling. Kold fornuft må erkende dette faktum, må afsløre det $\mathrm{i}$ al dets nøgenhed og opdage dets uundgåelige konsekvenser. 
Halvdelen af historien er mordets historie. På hvert af historiens blade er der linjer af blod, og hvis vi sammenligner menneskets slag med dyrenes, da kan vi udmærket behandle verdenshistorien som en fortsættelse af naturhistorien. Den afgørende forskel mellem den menneskelige og den dyriske historie om mord skal findes $i$ det faktum, at mennesket, $i$ det mindste $i$ det omfang de kalder sig 'civiliserede', myrder hinanden for ingen anden grund end at få den anden af vejen, hvorimod dyrene gør det for at få mad. For dyrene er det myrdede dyr på samme tid et nedfældet bytte, for mennesket er det myrdede menneske en fjernet forhindring. Dyret skal dræbe og vil altid være tilskyndet til at gøre det for at overleve; mennesket myrder, så længe han er et dyr eller behandler andre som dyr.

Du indvender, ærede dommer ved kriminaldomstolen, at mennesket adskiller sig fra dyrene ved at gøre mord til en soning for forbrydelser imod andre mennesker eller for 'forræderiske angreb'; at han helliggør det på sæt og vis som en 'dødsstraf'. Men jeg kan ikke engang indrømme dig den usle tilfredsstillelse, for der er sociale dyr (f.eks. tranerne), der lige som os har deres forbrydelser, som straffes med døden, og som udøver 'dødsstraffen' på de kriminelle in optima forma [symbolsk, o.a.] og endda in corpore [legemligt, o.a.]. Du ved ydermere sikkert ganske godt, at bierne myrder dronerne, som i deres samfund stort set repræsenterer det samme som Preussens hoffolk, officerer og andre driverter og snyltere. Du min gode løjtnant, du er på den anden side af den mening, at regulær krig er noget specifikt menneskeligt, og at der ikke er dyr, der myrder i hære. Heller ikke det kan jeg tilstå dig. Jeg kan højst lade dig beholde den stolte bevidsthed om, at dyr ikke har nogle krigsartikler, ingen eksercits-øvelser og ingen parader, mens de dog er fuldstændig ens i uniformer. Læs de spændende fortællinger i Okens naturhistorie om slag, hvor myrer kæmper i hære næsten så store som de preussiske og russiske hære. Du vil beundre disse små udyrs militære talent og på samme tid beklage, at de ikke er store og intelligente nok til at gøre dig eller den store Wrangel til øverstkommanderende.

Ærede dommer og kære løjtnant, den eneste form for mord, hvormed mennesket adskiller sig fra dyret, og som på samme tid - lige som mord som selvforsvar - har fornuft og retfærdighed på sin side kaldes for 'selv-mord'. Et menneskes liv tilhører kun ham selv, og kun han har ret til at ødelægge det. Det er ikke kun hans ret, men det kan også være hans storhed. Hvis en uundgåelig vanære, der ville ødelægge hans karakter, eller hvis et uvægerligt uheld skulle gøre hans liv nytteløst, truer ham, da skal han ikke fordømmes for at ende sit liv i koldt blod. Niobes karakter passer ikke til alle tilfælde af håbløshed, og en mandlig Niobe ville være topmålet af absurditet. Cleopatra, der på trods af sin kongelighed og brodermord, er en større kvinde end hun 
normalt anses for, lagde en giftslange for sit bryst for ikke at blive skændet af, at Octavian ville udstille hende i sin triumfprocession. Den yngre Cato gennemborede sig selv med sit sværd, fordi han efter Cæsars sejr ikke kunne leve længere 'uden at blive falsk overfor sine principper'. Brutus og Cassius, de 'sidste romere', tog deres egne liv, da slaget ved Philippi stoppede deres republikanske sag. Da Cæcinna Pætus, der blev anklaget for sammensværgelse imod Claudius, ikke havde andre flugtveje end døden, da stødte hans loyale kone Arria en kniv dybt ind $i$ hans bryst og gav da våbnet til hendes mand med de berømte ord: "Pætus, det gør ikke ondt". Robespierre prøvede at skyde sig selv, da det moderate parti ved hans anden indespærring truede ham med døden ved guillotinering. Konventets fjorten delegerede, der i 1795 var gået sammen med folket i kravet om 'brød og 1793-forfatningen', og som for dette var blevet dømt til døden, stak sig selv ihjel med den samme kniv, mens de råbte 'Længe leve republikken!'. Den ungarske revolutionære May dræbte sig selv i fængslet på den mest smertefulde måde ved at brænde sig selv til døde for at undgå sine fjenders inkvisitoriske tortur.

Som I ser ærede dommer og kære løjtnant så er disse - ved siden af mord i selvforsvar - eksempler på den eneste tilladelige og retfærdige form for mord. Hvis Mazzini efter oprøret i Milano var faldet i hænderne på de østrigske bødler, da ville han uden tvivl have brugt den gift, som han med al sandsynlighed bar på for præcis det formål. Ville I have bebrejdet ham det? Ville I i hans sted have tilladt Radetzskys vice-bødler at lægge jer på blokken og lade dem lægge rebet om jeres hals? Vær rimelige, og jeg skal være rimelig overfor jer. Jeg skal ikke hævde selvmordet som et revolutionært privilegium lige som I hævder mordet på andre som et reaktionært privilegium. Jeg skal derfor ved revolutionens begyndelse give jer retten til at ende jeres usle eksistenser med jeres egne hænder. Jeg skal endda tilstå jeres høje herrer retten til selvmord som Nero, så de derved redder sig fra at blive hængt eller at brænde sig selv inde i deres paladser som Sardanapalus med sine elskerinder og slaver.

Det store blodbestænkede billede, vi kalder historie, viser os mord i tusinde former og mordere med tusinde navne. Nogle gange kaldes det krig og morderne helte; nogle gange kaldes det oprør og morderne kaldes folket; andre gange kaldes det drab og morderne kaldes banditter etc. Det er altid det samme simple mål, nemlig at neutralisere opposition ved at ødelægge menneskeliv. Alt efter motiverne og omstændighederne så møder det forskellig kritik, der som regel er helt igennem pervers og servil. Retfærdighedens principper forbliver uforandrede gennem historien men deres genkendelse er kun mulig ved fri bedømmelse, hvorfor de sommetider er fuldstændig skjulte i længere perioder. Bedømmelsen af mennesket er som regel styret af, nej undertrykt af, det fremberskende faktum, således at de anerkender selv det fremherskende mord 
på trods af dets uretfærdighed, mens de fordømmer det besejrede mord på trods af al dets retfærdighed. For at opnå klarhed omkring mord, for at finde praktiske data for en korrekt vurdering, lad os da først se på nogle få former for mord i historiens store bloddrama.

Den første form for mord, som jeg vil kalde destruktions-mord, stammer fra den rene lyst til ødelæggelse. Ved romernes ødelæggelse af Jerusalem blev en million jøder dræbt. Da de samme helte ødelagde Kartago, var det kun halvtreds tusind ud af syv hundrede tusinde, der blev sparet. Spaniolerne og andre slagtede millioner af mennesker i Amerika uden grund og uden noget rationelt formål. Og hvor mange millioner af de uheldige stakler, der kaldes slaver, er blevet brutalt myrdet i såvel antikken som i vore dage på skibe, i plantager og i fængsler.

Næsten lige så morderisk som destruktions-kampene er de såkaldte regulare slag. Det siges, at tres tusind romere blev dræbt i slaget ved Cannæ. I slaget ved Chalons, hvor Aetius besejrede Atilla, faldt et hundrede og tres tusinde. Så hver 'helt' i de tusinder af slag, der fylder historien, tæller sine morderiske handlinger i tusinder og hundrede tusinder. Nationerne, 'soldaterne' bliver som regel betragtet som blodhunde og kanonføde. 'I hunde, vil I leve for evigt?' råbte Frederik den store, da de tøvede foran fjenden. De døde, som historiens store mænd fra Alexander til Napoleon brugte til at gøde deres laurbærkranse, skal tælles i millioner. Bare Napoleon sendte flere millioner til dødsriget for at kunne blive hersker over de overlevende og hans evner for mord skaffede ham titlen den store.

Lige så forbløffende som dumhed er, er også antallet af ofre, som dumbedens mord har krævet, dvs. de mord, som mennesker har begået imod hele nationer til ære for deres menneskelige eller overmenneskelige idoler. I historiens løb er der måske faldet flere undersåtter end soldater samt flere troende end barbarer. Korstogene til 'forløserens grav' var rent faktisk kun ligtoget for millioner af troende til deres egen grav. Trediveårs-krigen, krigen i hvilken vores forfædre igennem tredive år sloges om æren af at være i besiddelse af den største dumhed, berøvede Tyskland omkring fire millioner mennesker.

Dumhedens mord, mordet på undersåtter og troende, følges logisk af torturens og hævnens mord, mord begået af sekulare og andelige tyranner. Lad os tavst forbigå de millioner af ofre, der er blevet knust af tyranners vrede og begrænse os til massehenrettelser. Efter den endelige sejr ved Crassus over Spartacus' slaver blev seks tusind af dem sømmet fast til en dobbelt række af kors, der dækkede vejen fra Rom til Capua. Efter sin sejr over Dacianerne beordrede Trajanus ti tusind slaver til at møde op som gladiatorer i Roms cirkus og til at slås med elleve tusind vilde dyr, med andre ord, for sin egen fornøjelses skyld beordrede han en hær af mennesker og en hær af dyr at dræbe hinan- 
den. Potemkin fik tredive tusind tatarer (mænd, kvinder og børn) indfanget og massakreret, fordi de ikke ville 'hylde' kejserinde Catherine. Alba fik atten tusinde 'henrettet' i Nederlandene. Charlemagne (Charles 'den store') udryddede næsten hele det saksiske folk for at konvertere dem til kristendommen. De 'kristne' myrdede flere hundrede tusinde albigensere; bare i byen Bezière blev tres tusind nedslagtet. Ved hiælp af inkvisitionen dræbte præster hundredtusinder i koldt blod. Ved Sankt Bartholomew-massakren i Paris, efter hvilken den salvede leder af morderne, paven, beordrede en jubelfest, blev tredive tusind protestanter myrdet. I de tyske bondekrige blev hundrede halvtreds tusinde bønder myrdet. Hvis vi undersøger historiens lister over mord vil vi se, at størstedelen af mordene står på kristendommens side, kærlighedens religion. I kristendommens navn er flere blevet ekspederet til 'den anden verden', end der er trofaste kristne tilbage i verden. Kristus udviste derfor stor forudseenhed, da han sagde: "Mit kongerige er ikke af denne verden". Han kunne have sagt: "Mit kongerige er kirkegården".

Ud af det fulde antal mennesker på kloden, der vurderes til et tusind millioner, dør der én hvert sekund; og det er rimeligt at antage, at der i de fem væsentligste verdensdele myrdes én hvert minut, hvilket giver et tusind firehundrede om dagen eller et tusind fem hundrede i runde tal, hvilket igen er 547.500 om året eller i runde tal 550.000 mord. Selv hvis vi, idet vi tæller tilbage i historien, forudsætter, at antallet af mennesker bliver stadigt mindre, så finder vi på den anden side en stadigt stigende grusomhed, således at vi med rimelighed kan antage, at der myrdes 550.000 hvert år igennem hele historien. Hermed får vi den respektable sum af 2.000.000.000 mord for næsten fire tusind år, som 'guds skabninger' har bragt ud af verden. Hvis vi fraregner mord begået af præster, aristokrater og kongelige, så reduceres dette antal til en ubetydelig serie af individuelle mord. Det ville være et utroligt kedsommeligt arbejde at bevise korrektheden af denne sum gennem detaljerne $i$ historien af alle krige, slag, folkeslags migrationer, erobringer, undertrykkelser, henrettelser, kort sagt, af alle de forskellige mord og mordekspeditioner. Jeg har derfor begrænset mig til nogle få prominente eksempler, der tilbød sig ved et hastigt blik på historien. Meget er også blevet tilføjet af de millionvis af mord forårsaget af elendighed, mangel og forsømmelse, der dog alle må henregnes til de største mordere eller årsager til mord: kongerne, præsterne og aristokraterne. Det sorte sørgeslør, der er spændt ud over de sultendes bord, er lavet af deres forfædres ligklæde; og ethvert af historiens ligklæder er stemplet med en konges, ridders eller præsts våbenskjold.

I sammenligning hermed er antallet af mord begået af præsternes, aristokraternes og præsternes modstandere, af forkæmperne for retfærdighed og sandhed, ganske ubetydelige. Revolutionen har højest begået ét mord for hvert 
af reaktionens halvtreds tusinde. I det oprør, som Mithridates opildnede til i Lilleasien, siges hundrede halvtreds tusind romere at have faldet. Det er det største tilfælde af retfærdig hævn, som jeg kan huske; men der var brug for en konge til at gøre det, og i sammenligning med romernes grusomheder er det ubetydeligt. I krigene med Spartakus siges det, at flere romere faldt end under de puniske krige; men selv hvis 'alle' havde faldet, så kunne selv den skæbne ikke have kompenseret for bare halvdelen af deres skyld. Igen, hvad betyder de få tusind henrettelser under den franske revolution i sammenligning med de millioner af mord forårsaget af århundreder af reaktionær dominans, og som fremprovokerede denne folkelige eksplosion? Jeg minder bl.a. læseren om det faktum, at der ved revolutionens udbrud var fere millioner ofre for despoter og præster indespærret i Europas fængsler. Hvad betyder Harmodius' og Brutus' knive, Tells pil eller Fieschi og Alibauds forsøg i sammenligning med de utallige mord, hvormed tyranner får fjernet deres modstandere på alle tænkelige måder? Hvad betyder den tapre Libenys kniv, en af de største ungarske helte (der ganske vigtigt ønskede at knivstikke den østrigske Nero i nakken, som var han et vildt dyr) i sammenligning med de tusindvis af nedslagtninger udøvet af dette unge bæst i Ungarn og Italien? Fortjener et sådant udyr ikke at blive myrdet sammen med alle hans medskyldige? Cæsar, Tiberius, Caligula, Claudius, Galba, Otho, Vitellus blev myrdet. Fra Commodius til Konstantin den store blev 27 ud af 36 kejsere myrdet. Ud af alle disse tyranmord er kun den mindste del udført af frihedens venner eller af revolutionære, men forestil jer, at de havde myrdet dem alle: Er det overhovedet værd at nævne i sammenligning med den masseødelæggelse af menneskeliv, som disse tyranner forårsagede? Hvor mange mennesker myrdede Sulla ikke! Men han blev ikke straffet, da han trådte tilbage som diktator. Lus måtte udføre skarpretterens pligt overfor ham - mennesket $\mathrm{i}$ al dets forfald formåede det ikke. Triumviratet Antonius, Octavius og Lepidus havde blandt andre tre hundrede senatorer og totusinde riddere på deres dødsliste. Hvornår har revolutionære nogensinde konspireret om at udføre sådan et myrderi? Lige præcis den svaghed har altid været de revolutionæres afgørende fejltagelse; at de i deres dårligt udtænkte medmenneskelighed og udtømte energi har skånet uforbederlige reaktionæres liv; eller at de blændet af den ufornuftige glæde over deres sags angivelige sejr har fejlet med at opnå den i virkeligheden eller i det mindste at sikre den ved den fulde udryddelse af deres fjender. Når de står kaldet til at udøve retfærdighedens gudindes funktioner imod alle folkets fjender, da har de sænket gudindens sværd ved det første slag og kun beholdt hendes blindhed. En revolutionær, i hvis magt det ligger at udrydde alle repræsentanterne for voldens og mordets system, der hersker over verden og lægger den øde, fortjener at dø en forræders død tusind gange, hvis han tøvede bare et øjeblik. 
Ansporet af håbet om, at der meget snart vil opstå en anledning til at tage dette råd alvorligt, lad os da kaste et flygtigt blik på vor tids mordhistorie.

Frederick William den fjerde, denne Falstaff mellem Neroer, der er helt igennem brutal, fik sammen med sin bror, denne korporal mellem konger, indbyggerne i Berlin skudt ned i hundredvis, fordi de var blevet trætte af hans falske forklaringer; og da folket alligevel sejrede, da blev de kongelige mord ændret til 'misforståelser'. Den samme hykler beordrede en endnu større mængde mord og endnu mere skamfuldt i Saksen og Baden. Her var det bare ikke misforståelser, for folket blev besejret. Højdepunktet af morderisk vanære hævede han sig op til i Schleswig-Holstein, hvor han i den patriotiske æres navn lod venner og fjender myrde i tusindvis, i det mest afskyvækkende forræderi, som verden endnu har set, og det for at høste patriotisk vanære som morderens bytte, når forræderiet var udført. I den nuværende herre og mester af Berlin har preussisk politik fundet dets mest fuldstændige udtryk, dets mest udtalte personificering: ondskabsfuldhed beskyttet af hykleri, kujoneri beskyttet af forræderi, forbrydelse beskyttet af mord. Hævn!

Francis Joseph, det unge monster, født af en adlet hyæne og opfostret ved martyrblod, og samtidig gjort modløs af lyst før han blev voksen, minder os om de nedbrudte romere, der drak slaveblod for at genoplive deres spildte kræfter. Hvor mange mord er ikke allerede dynget oven på denne unge østrigske forbryder og hans gamle medskyldige! Bare hans gamle bøddel Radetzky har gennem krigsretten fået fire tusinde frihedselskere myrdet en efter en. Østrig er sammen med Ungarn og Italien blevet forvandlet til et stort slagterhus med ét enormt skafot, hvor tusindvis af bødler og deres assistenter arbejder dag og nat på at myrde på vegne af en lille knægt, og for hvem hans morderiske tjener Latours galge stadig venter forgæves på et mere nobelt ornament. Hævn! Hævn!

Det tredje medlem af ligaen er monsteret fra Sankt Petersborg, denne fornemme nations-morder. Med hvert skridt skræver han over lig, og hans trone er - lige som Tamerlanes trofæer - bygget af knoglerne fra de myrdede. Alle hans ord er dødsdomme, og hans iskolde ånde udsender forræderi og mord, med hvilke han planlægger at gøre hele Europa til en kirkegård af despotisme og en ørken af grusomhed. Han er heldigere end sine forgængere, idet han har udøvet sit morderiske arbejde i femogtyve år uden selv at blive myrdet. Mens hans forgængere blev myrdet af vagterne på deres palads, så er hans henrettelse måske reserveret til fremmede nationers befolkninger. Desværre er det en alt for lille tilfredsstillelse at se kosakkernes og kalmukkernes gud hænge fra en lygtepæl eller blive trukket af en ungarer eller polaks hest gennem sine lydige medskyldiges blod. Hævn! Hævn! Hævn!

Disse tre kriminelle er repræsentanter for det kristne selskab af mordere, der kaldes den hellige alliance, og som ønskede at realisere 'kærligheden og 
fredens religion' i politikken. Deres fred er kirkegårdens, og fra alle Europas grave skriger millioner af ofrene for deres 'kærlighed' på hævn. Deres ophav er kun mord, mord er deres politik og døden deres 'fryd'. Blod er deres alfa og omega. Blod er deres mål og deres middel. Blod er deres lykke og deres liv. Blod er deres drøm og deres stræben. Blod er deres princip, og blod må blive deres endeligt. Blod er det blæk, med hvilket den hellige alliance oversatte deres 'kærlighedsreligion' til politik. Revolutionen skal skrive deres dødsdom med lige så blodige bogstaver. Der hvor hængning og nedslagtning er politikkens eneste grundlag, der kan alene blod og mord ligge til grund for etikken.

Under disse tre allierede hovedmorderes auspicier har en række mindre tyranner i de sidste tredive år praktiseret morderens gerning med stor omhu lige fra botanikeren i Dresden, der gødede sine blomsterbede med blod til kirkegårdsgraveren fra Napoli, der omdannede halvdelen af sit land til grave for de døde og den anden halvdel til grave for de levende.

Med korset i den ene hånd og sværdet i den anden har banditten i Paris endelig forenet sig med dem; denne parvenu [opkomling, o.a.] i morderfaget, hvis vej til tronen gik over kvinder og børns lig. Sporene fra denne morders hånd udstrækker sig fra Paris til Lambessa, fra Rom til Cayenne. Denne blanding af bandit, jesuit og vagabond har overgået selv sine legitime forbilleder, hvad angår forræderisk ondskabsfuldhed og morderisk skruppelløshed.

Og hvad lærer vi fra den succes, der indtil videre har tilsmilet denne morder, og som har undergravet alle ideer om etik og alle læresætninger om retfærdighed? At en revolution, hvor det kun er de revolutionares blod, der blev udgydt, var en tåbelighed, en forbrydelse, hvis straf gjorde et regime af blodig respektløshed og skruppelløs beslutsomhed nødvendig. De reaktionæres blod skånes altid kun på bekostning af de revolutionære. Enhver revolution begår selvmord, hvis den fralægger sig ansvaret for at myrde reaktionen. Frankrig bøder mere for sine undladelsessynder end for sine handlingssynder. Lad hende gøre bod ved Robespierre og Barères grave, der fornuftigt har sagt: "Kun de døde vender ikke tilbage". Han kunne have tilføjet: "Kun de døde lyver og myrder ikke længere". Emigrationen begravede den franske revolution i både dette og det forrige århundrede. Lad os være opmærksomme på, at der næste gang ikke bliver nogen emigration, medmindre den kan stuves sikkert væk i et eller andet fjernt hjørne af verden.

Fra banditten i Paris går vi til hans protege i Rom. Burde paven ikke rejse til Paris? Det ville være et stort tab for mordets historie, hvis jesuitternes blodige hånd skulle afvise at salve det blodstænkede overhoved for allieret forbryderi med fordømmelsens hellige olie. Fra to republikkers grave stiger ligstanken op som en offerlugt for de to helliggiorte hoveder, og forbandelserne fra de myrdedes læber tilvejebringer hævnens akkompagnement for deres hæders $T e$ 
Deum [tidlig kristen lovprisningshymne, o.a.]. Kristus døde på korset på trods af, at han ikke havde dræbt nogen; hans seneste 'efterfølgers' hånd drypper af de myrdedes blod, og han lever stadig; han lever på et Golgatha af frihedskæmpere. Hvis han blev korsfæstet, da ville der hænge flere end to forbrydere ved hans side, som han ville kunne sige til: "Snart vil I være med mig - i helvede". Hans læber udtaler en 'velsignelse' af ethvert forræderi, enhver ugerning, ethvert fuldbyrdet mord - så sandelig ingen upassende brug af denne 'velsignelse'. Hele hans mission er begrænset til at helliggøre enhver ugerning, som ondskab kan opfinde og grusomhed udføre; den er den sidste rest af en overtro, som et præsteskab har formidlet til verden i atten århundreder. Et værdigt endeligt for Kristus' efterfølger! De hævnende flammer, der vil brænde tyranniets skafotter til aske, er allerede begyndt at knitre; og når I slyngler råber om hjælp i flammerne, da vil selv den sidste af jeres tilhængere svare jer med hævnens ord og udbryde: "Tilgiv dem ikke, for de vidste, hvad de gjorde!"

Ja, de vidste, hvad de gjorde. Lad os sikre os, at også vi ved, hvad vi gør!

Vi har dem nu foran os i alle mulige former, mordets repræsentanter. Der står de og afventer vores dom og vores beslutsomhed. De fortæller os med prisværdig beslutsomhed: "Vi myrdede, vi myrder og vi vil myrde, så længe vi kan. Vi myrder for at herske, ganske som I må myrde for at kunne blive frie. Der kræves ikke mere diskussion om, hvorvidt mord som et historisk middel er et faktum - vi fastslår det som sådan; ikke mere diskussion om, hvorvidt det er en uundgåelig nødvendighed - vi fastholder det som sådan; ikke mere diskussion om, hvorvidt det er retfærdigt - vi myrder. Sig hvad du vil, og gør hvad du kan: 'Sejrherren har ret'.'

Ikke desto mindre har sejrherren ret. Findes der en offentlig mening, som tværs over havene vil kunne trække sejrherrerne op på deres ofres grave? Findes der en magt, et tribunal, der vil kunne brændemærke disse forbryderiske kolosser? Finder der en gabestok, der vil holde dem fanget så højt, at deres fødder, der tramper alle ting ned, ikke kan nå jorden? Er det ikke sådan, at alle op til i dag kalder det for regering, der egentlig kun er mordets styreform, svardloven, i dens mest kolossale dimensioner? Det er ikke middelalderen, der var sværd-lovens tidsalder. Den har først nået sin blomstringstid i vor tidsalder, og hvem kan bremse den? Så snart de har besteget tronen, bliver morderne og banditterne da ikke respekteret, fejret og bejlet til selv af republikkernes repræsentanter? Hvor er da den magt, den offentlige mening, det tribunal, der ville kunne dømme den kronede forbrydelse? Sejrherren har ret - det er 
den visdom, som alle bukker for, som alle hylder, selv den 'højeste dommer' i himlen og den dydige Mr. Pierce i Washington.

Reaktionen har kun værktøj; kun revolutionen har martyrer. Men selv dette privilegium er blevet frarøvet jer af despoterne. De har øget antallet af martyrer så meget, at martyriet ikke længere giver mening. I dag falder frihedens martyrer som et visnet blad fra et træ - i løbet af natten blæser det væk og glemmes som tusinder af andre. Kriminalitetens overherredømme, voldens overherredømme, sværdets overherredømme, mordets styreform er så fuldt ud anerkendt, så veletableret, er blevet så 'legalt' og universelt, at dets ofre knap kan finde en flygtig sympati i det stille skjul. Ungmøen sørger over tabet af sin kærlighed, moren tabet af sin søn, der tilfældigvis også var en martyr for frihedens sag. Det lukker dramaet; friheden tager ingen notits af det, og mordet fortsætter med at herske uforstyrret. Sejrherren har i sandhed ret og 'stakkels den besejrede!' er den eneste trøst, den slagne hører.

Menneskehed! Du har mistet din samvittighed og din fornuft. Du anerkender, at sejrherren har ret, det vil sige, at mordet er ret. Du kan kun genvinde din samvittighed og fornuft, hvis du ønsker at afskaffe mord ved at vende dig imod alle mordere; hvis du vil udvirke, at retten kontrollerer mordet, hvor mordet $i$ dag kontrollerer retten. Medkæmpere for frihed, retfærdighed, sandhed og menneskehed! Lad vores studium være mord, mord i enhver form. I det ord ligger mere menneskelighed end $i$ alle vores teorier; og hvis sentimentale psykologer skulle forvirre jer ved at anklage jer for hjerteløshed, husk da at den mest menneskekærlige statsmand, den mest humane personlighed, den mest varmhjertede alle den franske revolutions mænd var - Robespierre.

I gode folk hinsides havet, der til den systematiske amoralitets store fornøjelse fortsætter med at forvirre jer selv med moralske skrupler: har I ikke i jeres læreanstalter og med tilladelse fra den højeste autoritet hørt digte, hvor "Meros med en kniv under sin kappe sneg sig ind på tyrannen"; hvor attentatmanden Tell blev hyldet som befrier, fordi han fra et sikkert skjul skød en tyrans slave? Har I ikke hørt jeres loyale lærere hylde Brutus, der dolkede sin egen far og de 'heroiske unge' Harmodius og Aristogiton, der myrdede tyrannen Hipparchus? Hvorfor er disse attentatmænd moralske og store mænd selv hos vores egne tyranner og deres legale og loyale skolemestre? Fordi de tilhører fortiden og ikke nutiden, tilhører historien og ikke livet? Oversæt dem fra latin og græsk til russisk og fransk, og de vil blive beskrevet som 'amoralitetens monstre', og det selv om en Harmodius ville være mere passende i Sankt Petersborg og en Brutus mere passende i Paris, end de ville være i det antikke Athen og Rom. Nej, Schweiz, der i dag fejrer mindet om attentatmanden Tell på væggene af hvert eneste hus, hele Schweiz bliver målet for forfølgelse fra alle de reaktionære blodhunde, når en tysk Tell affyrer bare en revolutionær 
tankepil fra sit kogger. Foretag din egen anvendelse af denne logik. Hverken despoterne eller republikanerne afviser mord som 'amoralsk', men de anser det kun for moralsk, når de selv praktiserer det, eller når det tjener deres interesser.

Lige præcis sådan er det med dommen over og udførelsen af det fuldbyrdede mord, af det organiserede mord der kaldes krig. De kontrollerer mordets moral ganske som al anden moral for at lænke alle, så de kan træde dem under fode. Og historien, den 'retfærdige dommer', den 'endelige dom' lakker som sædvanlig bagud med sin dom; og selv når hun dømmer, da er det ofte i overensstemmelse med 'sejrherrens' vilje. Generelt lærer historien os, at: I fortiden var det den mest retfærdige, der vandt, og i nutiden er det den stærkeste; I hele fortiden var det retfærdigheden, der bestemte, men i nutiden den stærkeste; I fortiden var det retfærdigheden, der bestemte, men i nutiden er det partiet; I fortiden var det idealet, der gav beslutningsgrundlaget, men i nutiden er det formålstjenstlighed; I fortiden burde retfærdigheden have sejret, men i nutiden 'har sejrherren ret'. Endelig lærer historien os, at forbrydelse straffes ved galgen, hvis forbrydelsen er for svag til at beskytte sig selv; men at den forvandles til en 'ret', så snart forbrydelsen har styrken til at rense sig selv. En bandit og hans medsammensvorne gør nogle få distrikter usikre. Den 'bevæbnede autoritet', gens d'armes [sværtbevæbnede ryttere, bliver senere til gendarmer, o.a.], påkaldes for at jage ham og sikre 'respekt' for loven. Han fanges og hænges som soning for fortiden og som advarsel til fremtiden. Men forestil jer, at han lykkedes med at besejre den 'væbnede autoritet'; han omstyrter 'loven'; han tager landet i besiddelse; og han gør sig selv til hersker. Da forvandles hans 'forbryderbande' til en 'hær', 'banditlederen' bliver 'general', 'banditten' forvandles til en 'konge' og den udplyndrede befolkning forvandles gradvist til loyale undersåtter, der med stor entusiasme råber: "Længe leve vores mest nådige konge!" På denne måde er alle vores konger og kejsere opstået; og for at minde os om deres oprindelse er de nu, åbent og uden forbehold, blevet til banditter igen. De beror på maksimen: Sejrherren har ret på trods af mord og tyveri. Men selv hvis denne sejrherre har 'ret', hvem har da virkelig uret? Hvor meget mere 'ret' må den have, der i sandhed har en retfærdig sag? Hvordan han end har opnået sejren: Det er kun sejren, der tæller. Om vi opnår sejren med krudt eller gift, med sværd eller kniv, med kviksølv eller kanon - det gør overhovedet ingen forskel. Erobr din fjende; udslet din fjende - det er det eneste, der tæller. Historien vil dømme os efter det, og vores skæbne vil kun blive bestemt af den brug, vi gor af vores sejr, ikke af den måde vi vandt over vores fjender, der har bortvist ethvert menneskeligt hensyn fra verden.

Den største af alle verdens dumheder er troen på, at det er muligt at begå en forbrydelse imod despoter og deres medsammensvorne. Selve denne forestilling 
er en forbrydelse. Hvis man kunne skyde den, da ville det være en forbrydelse at skåne den tiger, der hærger et samfund af forsvarsløse mennesker. Despoterne er fredløse lige som tigerne. Despoterne tilhører dyreriget. Da despoterne og deres medsammensvorne mener sig berettiget til at gøre hvad som helst - forræderi, gift, snigmord og deslige - da er det tilladeligt at gøre hvad som helst imod despoterne og deres hjælpere - forræderi, gift, snigmord og deslige. En forbrydelse imod dem er ikke kun en ret men en pligt for enhver, der har muligheden derfor; og det vil blive regnet til hans ære, hvis han er succesfuld. Kun menneskevæsener har en hensynsetik; for dyr er der kun en destruktionsetik. Kun i friheden, kun i det sande demokrati, kan der være et perfekt etisk kodeks, og der er brugen af vold en forbrydelse imod hele folket. Men voldens primat er en tilladelse til enhver 'amoralitet', der kan bringe volden til ophør. Despoternes 'love' er kun sværdets dekreter; deres 'ejendom' er kun tyvekoster; deres straffe er rent 'mord'. Ingen kan begå en 'forbrydelse' imod deres 'love'. Ingen mand af folket kan 'berøve' dem deres 'ejendom'. At slå disse morderiske herrer ned gør den revolutionære til menneskehedens befrier.

I alle kampe mellem reaktion og revolution er det selvindlysende, at reaktionen er den eneste aggressive part. Revolution er kun selvforsvar. Mord i selvforsvar er ikke kun tilladt; det er også en pligt overfor samfundet, når det er rettet imod en professionel morder. Selvforsvarets såvel som revolutionens fejl består i tilfredsheden med det umiddelbare resultat uden at bruge sin sejr til at sikre garantier for fremtiden. En bandit angriber en rejsende, bliver afvæbnet af ham men får sit liv skånet. Det giver banditten muligheden for at gøre et bedre job imod den rejsende næste gang og udsætter også den rejsende venners liv for fare. Ligeledes er det med revolutionen. Det er dumhed og selvbedrag, hvis den begrænser sit selvforsvar til øjeblikkets resultat. Den skal gore op med reaktionens hiælpere, dens repræsentanter, for revolutionens fjender er uhelbredelige, lige som den afvæbnede bandit eller den skånede tiger. Vi kender vores fjender. Vi kender dem alle sammen og alle steder personligt. Der er ikke længere nogen undskyldninger, hvis de igen bliver skånet. Hvem der end står på den anden side af den linje, der adskiller de herskende magter fra folket, er fordømt. Lad folket eksekvere dommen, og lad dem kun skåne dem, der var vildledt, tvunget eller magtesløse.

Vejen til menneskelighed går over grusomhedens bjergtop. Det er nodvendighedens ubønhørlige lov, som reaktionen dikterer til os. Vi kan ikke undvige den, medmindre vi afsværger os fremtiden. Hvis vi vil nå målet, skal vi bruge midlerne. Hvis vi skal sikre folkets liv, så skal vi sikre os dets fjenders død. Hvis vi skal give menneskeheden oprejsning, da må vi ikke vige tilbage - fra mord.

Der er berømte revolutionsledere, der sidder inde med midler og indflydelse. Spørg dem, om de billiger mord. De ville vende sig væk i rædsel, for 
de ønsker ikke at miste anerkendelse som 'moralske'. De ønsker at være 'fornemme' revolutionære. De er reaktionære, fornemme forrædere. De former deres etik $i$ overensstemmelse med holdningen hos dem, der er fjender af revolutionen. At få respekt fra filisterne, gamle koner og reaktionære er vigtigere for dem end deres standpunkt, end revolutionens formål. Med deres midler og indflydelse kunne de gøre mord til en folkesag. De kunne for længst have udryddet de fremmeste repræsentanter for mordet og derved frigjort revolutionen. Men de har vigtigere ting at give sig til. De må ødsle deres midler på unyttige sammensværgelser for at levere deres fjender til skafottet og for at holde bødlerne beskæftiget. Det højeste, som deres revolutionære beslutsomhed når til, er håbet om en dag at kunne besejre deres fjender på 'slagmarken' med samme våben som fjenden. Forbløffende galanteri! Fader Radetzky, der dag og nat er optaget af mord, udtalte sig for nylig efter Milano-oprøret med den størst mulige moralske indignation om 'snigmord'. Lån os din hær af mordere, fader Radetzky, eller deres våben, og vi skal ikke længere have behov for 'snigmord'. Vi skal da myrde åbent i 'kamp' eller ved 'krigsretten' afhængig af dine ønsker. Vores mest berømte revolutionære deler fuldstændig fader Radetzkys standpunkt. De tillader fjenden, der besidder alle midlerne til angreb, og som har stillet alle midlerne til forsvar udenfor vores rækkevidde, at bestemme forsvaret. Det ville være en helt ny politik, hvis panteren i cirkus skulle lade bøflen bestemme, at den skulle beskytte sig med horn imod bøflens horn og ikke amoralsk snige sig ind på bøflen bagfra. Bøflen Radetzky kræver, at de revolutionære, fuldstændig ubevæbnede, skal møde ham efter en højtidelig krigserklæring, åbent og in optima militari [i fuld udrustning, o.a.] med kanoner og ammunitionstog, med kavaleri og infanteri. Er hr. Kossuth ikke enig med ham?

Efter udbruddet af Ungarns-krigen annoncerede aviserne, at ungarerne brugte kæde-kugler, men at de havde opgivet disse missiler, der er endnu mere effektive end østrigernes Congreve-raket, da Windischgraetz informerede dem om, at 'krigens skik og brug' var imod deres anvendelse. Stakkels ungarere! Hvis det er muligt at skyde med gift, da må man håbe, at I vil gøre det næste gang.

Da østrigerne marcherede ind i Raab, annoncerede de reaktionære aviser med den mest ekstreme moralske indignation, at kødet var blevet forgiftet. Det er en skam, at de østrigske blodhunde ikke åd det. Men der er berømte revolutionære, der anser det for en større synd at forgifte en hær af blodtørstige blodhunde end en hær af uskyldige rotter. Forestil jer, hvis schweizerne ved Napoli eller østrigerne ved Milano en dag skulle dø af forgiftet vand eller fra en kviksølvsbombning af deres barakker; ville alle de fornemme republikanere da ikke beklage, at de ikke var blevet dræbt af kanonkugler? 
Mine herrer, fysik og kemi kan blive meget vigtigere for revolutionen end al jeres galanteri og militærvidenskab. Hvis vi med hjælp fra gift og ild kan gøre riddere og generaler overflødige, da vil vi have den dobbelte fordel, det er at blive af med ikke bare reaktionen men også af det soldatervæsen, de har etableret; og som det ser ud til, at 'frihedens riddere og helte' vil beholde af ren glæde over dets brogede romantik, selv hvis der ikke var flere fjender at nedkæmpe. Når vi betragter, hvor lidt visse revolutionære bestræber sig på at korrumpere hærene, da fristes vi til at antage, at de er bange for derved at underminere det prægtige soldatervæsen, som de selv ønsker at besidde.

Her er der andre fornemme revolutionære, der siger: "Der er ting, der kan gøres, men som ikke bør nævnes." Det er kujoneri. Det, du ikke vover at nævne, bør du heller ikke tillade at gøre. Det rette, hvad end det er, bør nævnes åbent overfor hele verden, så det kan gøres som en ret. Hvis en bestemt handling af praktiske hensyn kræver hemmeligholdelse, da bør vores handlingers store principper hånligt afvise den. Jeg prædiker åbent mordet på despoter, fordi det er en ret, fordi det er en pligt, fordi det er den eneste måde at redde menneskeheden fra mordets herredømme, og fordi det skal anerkendes som universelt tilladt og retfærdigt. Jeg ved, at man ikke kan stole på de berømte ledere; at de er mere optaget af deres ry for gode manerer end for radikal revolution, og at de reaktionæres liv er tryggest i deres hænder. Derfor bestræber jeg mig på at gøre mord på despoter til en folkesag, således at folket, hvis det vil leve demokratisk efter revolutionen, draber demokratisk og ved alle lejligheder, uden overhovedet at tænke på de fornemme, store mænd.

Men, siger du, hvorfor foregår jeg ikke disse store mænd med et godt eksempel? Hvorfor forsøger jeg ikke at gøre det, de store mænd ikke magter? Spar dine spørgsmål, dig der bortødsler handlingens midler til enhver eventyrer eller pralhals, så han kan bruge dem til ingen nytte eller 'sætte dem i banken og få renter'; dig, der ikke engang betaler for papiret til dem af fornuft og beslutsomhed, der på det papir kunne irettesætte dig for din mangel på fornuft, din inaktivitet, din mangel på energi, din smålighed og din skurkagtighed.

Nok om det. Tyranmordsdoktrinen bør være lige så kort som mordet selv. Der mangler endnu kun én ting. Det var ikke min hensigt at udgyde blod og udslette tyranner på papiret bare for at sikre lindring til den længe undertrykte vrede over en verden fuld af hidtil uhørt skændsel og skændige handlinger. Det var for det forste min hensigt at ødelægge det falske etiske kodeks; at udslette de 'moralske skrupler' der holder tusinder af særligt vores landsmænd fra beslutsom handling, selv når muligheden ligger frit åben. Det var min hensigt at give oprejsning til ikke bare revolutionens mål men også dens midler, herunder snigmord, og at gøre mord lige så legitimt som tyrannerne har gjort med deres drab i krig, deres 'legale' mord, deres 'krigsrets'-henrettelser. Det var 
yderligere min hensigt at give fingerpeg om, hvordan man kan øge og udføre destruktion. Despoternes sikkerhed hviler udelukkende på deres destruktionsmidlers overlegenhed. Fjern deres soldater eller ødelæg deres geværer, og de falder skrækslagne og klynkende til jorden ved fødderne af deres undersåtter. Det første mål må derfor være at udligne den overlegenhed, de får fra de masseødelæggelses-maskiner, som vi ikke besidder og ikke vil kunne besidde. Det kan gøres ved homøopatisk brug af stærkt destruktive stoffer, som det kun vil koste lidt at anskaffe sig, og som let kan erhverves eller laves med ringe risiko for at blive opdaget. Jeg er hverken soldat, kemiker eller ingeniør, og jeg må derfor overlade det til professionelle at bruge de følgende eksempler for fremtidige handlinger.

1) 'Augsburg General Gazette' den --- rapporterer: 'I går eftermiddag fandt den moderne histories mest forfærdelige og sørgelige handling sted. Da de strålende, kronede hoveder af Tyskland var samlet til en kongres for monarker i Wien, tog de en togtur. En forfærdelig eksplosion hørtes på et sted, hvor sporet $i$ hundrede fods højde passerer en afgrund. På samme tid faldt lokomotivet og hele togsættet ned i afgrunden. Alle monarkerne knækkede halsen og kun to elskerinder slap med livet i behold, således at Tyskland lige nu er uden monarker. En undersøgelse har vist, at et revolutionært monster har lagt en lille kasse på størrelse med et fingerbøl fyldt med knaldkviksølv på sporet, og at det eksploderede ved den første kontakt med lokomotivets hjul, hvorved toget blev kastet af skinnerne. En lignende handling siges at have overgået zaren af Rusland i området omkring Warszawa."

2) 'Wiener-gazetten' den --- skriver: 'Guerillaerne fra Baconyan-skovene bruger nu det følgende frygtelige våben, der er beregnet på at gøre individer i stand til at gøre organiserede masser rædselsslagne. De har pistoler, der er dobbelt som tykke som ellers. Disse bliver først ladet med en stærk ladning krudt og på toppen af dette lægges en jernkapsel, der passer perfekt til pistolløbet, omkring seks centimeter lang og kegleformet øverst. Inde i denne kapsel er der en anden og mindre kapsel fyldt med krudt, der også er lukket øverst med en letantændelig fænghætte og rummet mellem den indre og ydre kapsel er fyldt med forgiftede jernhagl. Når denne ladning affyres imod et mål, eksploderer kapslen og spreder en byge af forgiftede hagl, som hver især kan ødelægge et menneskeliv. På denne måde kan et enkelt menneske omnia secum portans [bærende alt med sig, o.a.] blive farlig for hundreder af modstandere. En sådan ladning blev for nylig affyret fra skoven imod en bataljon af imperialt let kavaleri. Tres blev såret, og af dem var halvtreds døde den næste dag."

3) 'Preussens Statsgazette', der nu udgives i Potsdam, skriver den ---: 'Desværre har general Wrangel fuldstændig mislykket med at generobre Berlin, der nu helt og holdent er i hænderne på revolutionære. Han blev hindret af 
en desperat forsvarsmetode, hvormed rebellerne fuldstændig demoraliserede tropperne. Først skød de jernrør fyldt med flydende bly, der spredte en dødelig regn ned over de fremmarcherende bataljoner. På trods af dette trængte de tapre soldater ind $\mathrm{i}$ adskillelige avenuer tilskyndet af prinsen af Preussen med løftet om at kunne plyndre byen og henrette alle revolutionære på stedet. Men de blev mejet ned i dynger af eksplosive bomber, der pludselig sprang fra gadebelægningen, og som skabte så forfærdelig en ødelæggelse, at selv den mest tapre soldat ikke kunne nødes til at fortsætte videre, da de ved hvert skridt måtte frygte en ny eksplosion. Det siges, at disse eksplosive bomber bestod af granater fyldt med krudt og udstyret med en fænghammer, der er gravet ned under gadebelægningen på steder, hvor fjenden ikke kan opdage den, og på en sådan måde, at hammeren aktiveres, så snart en fod træder på stenene over den. Det siges, at de revolutionære har lagt lignende bomber $i$ alle avenuer, og at det ville koste hundrede tusind soldater livet at indtage byen. Det ser ud til, at revolutionens mænd ikke længere anser det for nødvendigt at risikere deres liv i nytteløse martyrier, hvis maskiner kan sikre dem succes. Så snart vores nuværende krigsførelse er overvundet og desorganiseret, da vil hæren og monarkerne være fortabte."

4) 'Milano-gazetten' den --- rapporterer: 'De fortvivledes parti har nu adgang til i sandhed diabolske midler. Enhver, der har nogen som helst værdi for samfundets orden og moral, må hver dag og nat ryste af skræk for sit liv. Gift er de revolutionæres universelle slagord, da de er berøvet alle andre våben. Vi har tidligere rapporteret om tilfælde af forgiftning af soldaternes fødevarer, vand, tobak og så videre. Men deres djævelske opfindelse har udviklet sig. Enhver kniv, sværd, enhver nål der rettes imod ordenens mænd er nu forgiftet. Til dette formål bruger de stryknin, preussisk syre med mere, ja endda blodet fra lig.

Med hidtil uset raffinering af grusomheden bruger de endda materien fra revolutionære, der er rådnet til døde i fængslerne som giftstof, og de retter disse forgiftede våben imod de mest hellige liv. Således blev lederen af jesuitterne og to kardinaler såret på denne måde for nylig. De vil dø inden for tre dage. Hans hellighed undslap kun en lignende skæbne af den dyne af fedt, som kniven sank ind $i$.

Til forgiftningen af kuglerne bruger de revolutionære, der nu alle steder ivrigt studerer fysik og kemi, kun gifte, der ikke alt for let ødelægges af varme. De bruger også glaskugler fyldt med kviksølv og endda med preussisk syre, der selvfølgelig dræber helt sikkert, hvis deres indhold kommer i kontakt med blodet. Når de fylder de hule metalbolde med gifte, der smelter sværere, da mikser de dem først med voks eller talg for så vidt muligt at undgå, at de ødelægges ved opvarmningen. 
De affyrer deres forgiftede missiler med luftpistoler fra vinduer, kældre, huller i murene og så videre, således at man ikke hører nogen eksplosion. Men siden adskillelige af disse våben er blevet fundet, bruger monstrene simple trunker eller pibestilke en eller to fod lange lavet af tin eller træ, ja endda makaronistænger, som de overalt skyder imod deres fjender, selv i kirker; ærter og små pile med forgiftede skarpe spidser. De behøver kun ridse $i$ huden for at producere en dødelig virkning, og det er sjældent muligt at finde gerningsmanden.

Hele vores krigskunst og alle vores kanoner er magtesløse overfor denne homøopatiske krig ført af en diabolsk modstander. Det er i disse tider en frygtelig opgave at være et ordensopretholdende menneske. Selv loyale mennesker udtrykker tvivl om, hvorvidt denne orden er gået for vidt. Men hvordan kan man være moderat med orden? Vi må nu myrde alle, ellers bliver alle vi myrdet. Gode forsyn, forlad os ikke!"

5) En korrespondent for 'La France' står inde for følgende beskrivelse: "Opfindsomheden hos revolutionens mænd, når det kommer til produktionen af nye destruktionsmidler, har sin lige i den forsigtighed, der udøves $\mathrm{i}$ deres agenters organisering og anlæg. Øverst blandt disse mordere, som de kalder befriere, er en enkelt person, hvis navn endnu ikke er blevet nævnt i den revolutionære verden, men som på grund af sin pålidelighed og kløgtighed nyder fuld tillid fra de vigtigste ledere. Denne person modtager fortløbende større summer af penge uden at vide, hvorfra de kommer. Det er hans primære opgave at få nye destruktionsmidler udviklet og produceret samt at finde pålidelige agenter, der kan bruge dem. Disse assistenter, fanatiske mænd med ekstrem beslutsomhed og pålidelighed, lever under alle mulige forskellige identiteter, kender ikke hinanden, og kommunikerer kun med deres leder, der besøger dem, hvor de bor, og hvis bopæl de ikke kender. Det siges, at der alene i Frankrig og Italien er hundredvis af sådanne agenter. Det er så meget vanskeligere at undslippe dem, fordi hvis en særligt vigtig person er deres offer, da retter de alle deres angreb imod ham på samme tid. Hvis en af dem skulle blive opdaget og arresteret, så kan han ikke forråde de andre, selv hvis han ville, og disse andre er samtidig i fuld gang med at tage hans plads og hævne ham.

Denne organisation af mordere er fuldstændig uafhængig. Men ved siden af den findes der en stor revolutionær organisation, der står klar til at udnytte muligheden for at erobre magten, hvis det offer, der blokerede dets vej, skulle falde."

6) 'Moniteur' den --- skriver: "Hans majestæt, kejser Louis Napoleon og paladset Tuileries findes ikke mere. I går nat blev paladset pludselig sprunget i luften ved en forfærdelig eksplosion, der begravede kejseren og hele hans føl- 
ge, der netop havde samlet sig omkring ham, under ruinerne. Et frygteligt coup d'etat [statskup, o.a]. Eksplosionen skyldtes et par kobberkugler på størrelse med en menneskehånd. Disse kugler var blevet fremstillet af en revolutionær og anbragt på en lavere etage af en soldat. Størstedelen af hver kugle var fyldt med nitroglycerin eller, som nogle påstår, med kulsyre, der som bekendt har langt mere sprængkraft end krudt, og som eksploderer ved en simpel temperaturstigning (dets effektivitet øges betydeligt, hvis kulsyren først gøres flydende ved hjælp af tryk). For at skabe opvarmningen af gassen inde i kuglen, var kuglen blevet udstyret med et ur, hvis indstilling var sat til efter en halv time at antænde en lille mængde fosfor og krudt ved hastig friktion. For at undgå en opvarmning udefra og dermed en for tidlig eksplosion var kuglerne indkapslet $i$ is; og for at undgå antændelse, idet de blev rullet ind $i$ kælderen, var de pakket ind i et klæde af indisk gummi. Så effektive metoder kan kun de revolutionære bruge. Men tiden for beklagelser er ovre, og en ny æra begynder. Revolutionen har sejret og sejrherren har ret. 'Moniteur' tjener altid vinderen. Vae victis! [Stakkels de besejrede, o.a.]" 
